\title{
Towards genetic transformation of local onion varieties
}

\author{
Pablo Marinangeli* \\ Departamento de Agronomía \\ Universidad Nacional de Sur \\ CERZOS (CONICET-UNSUr) \\ Bahía Blanca, Argentina \\ Tel/Fax: 542914862882 \\ E-mail: pamarina@criba.edu.ar
}

\section{Bernardo Deluchi}

Departamento de Agronomía

Universidad Nacional de Sur

Bahía Blanca, Argentina

Tel/Fax: 542914862882

\section{Raúl Ríos}

Instituto de Genética Ewald A. Favret CICVyA, INTA

De los Reseros y Las Cabañas s/n Castelar, Argentina

Tel/Fax: 5411 4450-0805/1876

E-mail: rrios@cnia.inta.gov.ar

Pascual Franzone

Instituto de Genética Ewald A. Favret CICVyA, INTA

De los Reseros y Las Cabañas s/n

Castelar, Argentina

Tel/Fax: 5411 4450-0805/1876

E-mail:pfranzone@cnia.inta.gov.ar

\section{Claudio Galmarini}

EEA INTA La Consulta

cc. 8, La Consulta

Mendoza, Argentina

Tel/Fax: 542622470304

E-mail: cgalmarini@fca.uncu.edu.ar

Fernando Rosselló

Departamento de Agronomía

Universidad Nacional de Sur

CERZOS (CONICET-UNSUr)

Bahía Blanca, Argentina

Tel/Fax: 542914862882

E-mail: rossello@criba.edu.ar

\section{Néstor Curvetto}

Departamento de Agronomía

Universidad Nacional de Sur

CERZOS (CONICET-UNSUr)

Bahía Blanca, Argentina

Tel/Fax: 542914862882

E-mail: ficurvet@criba.edu.ar

Website: http://www.criba.edu.ar/cerzos/

Financial support: Secretaría de Ciencia y Tecnología, UNS, Agencia Nacional de Promoción Científica y Tecnológica (PICT 08-12671) and the Consejo Nacional de Investigaciones Científicas y Técnicas (CONICET).

Keywords: Agrobacterium tumefaciens, Allium cepa L., callus, zygotic embryos.

Abbreviations: ME: mature zygotic embryos

MSc: callus induction medium

MSr: regeneration medium

*Corresponding author 
The aim of this work was to explore the possibility of obtaining transgenic plants of onion varieties cultivated in Argentina, starting from calli induced from mature zygotic embryos, using two strains of Agrobacterium tumefaciens as transfection vectors. Mature embryos from three varieties of 'Valenciana' onion, Torrentina, Cobriza INTA and Grano de oro were in vitro cultivated for callus induction. After three to four months an average of $57.4 \%$ success for the three varieties was reached. Transformation was carried out with Agl1 or LBA 4404 A. tumefaciens strains, both carrying a binary vector containing the marker gene gus $a$ and the selection gene nptII. Selection was done in callus induction medium containing $10 \mathrm{mgL}^{-1}$ geneticin during three subcultures. At the end of the selection period, 342 portions of calli were recovered and transferred to regeneration medium. Of the selected calli evaluated by the expresión of the $\beta$-glucuronidase enzyme, $42 \%$ presented extensive blue areas or were completely blue. At the end of the first subculture in the regeneration medium, 54 calli were considered potentially organogenic because of the green areas observed. At the end of the wole regeneration period, just one normal plant was obtained, that was negative to PCR analysis using specific primers for gus $a$ and nptII. All selected calli came from the Torrentina variety and the highest quantity of them were transformed with the strain LBA 4404.

On the frame of a good strategy directed to strengthen the genetic traits introduced by transformation, transgenes should be introduced in plant cultivars which are agronomically superiors and susceptible of being introduced in new plant breeding plans (Lydiate et al. 1995).

Eady et al. (2000), first reported an onion transformation protocol, based on immature zygotic embryos as target tissue. A drawback for this approach is that explant availability is limited to a short period during the year. Recently, Zheng et al. (2001) reported a reliable transformation protocol for onion and shallot (Allium cepa L.) using Agrobacterium tumefaciens as a transfection vector, and three-week old calli induced from mature zygotic embryos as target tissue. Since seeds are both easy to get and to preserve, for a successful onion transformation would be advantageous to use calli derived from mature zygotic embryos as target explant, because they can be used year-round (Zheng et al. 1998; Zheng et al. 1999).

Hence, the aim of this work was to explore the possibility of obtaining onion transgenic plants from varieties cultivated in Argentina, from calli induced from mature embryos, using two strains of $A$. tumefaciens as transfection vectors.

\section{MATERIALS AND METHODS}

Mature zygotic embryos from three onion varieties of Valenciana, i.e. Torrentina, Cobriza INTA and Grano de Oro, were in vitro cultivated in a callus inductive medium during three culture periods, 40 days each. The MSc was Murashige and Skoog (1962) which also contained $1 \mathrm{mgL}^{-1}$ 2,4- dichlorophenoxiacetic acid, $0,1 \mathrm{mgL}^{-1} \quad 6$ bencilaminopurine, $30 \mathrm{gL}^{-1}$ sucrose and $8 \mathrm{gL}^{-1}$ agar, $\mathrm{pH} 5,8$. Thousand and fifty ME were cultivated: 662, 178 and 210 of the Torrentina, Cobriza INTA and Grano de Oro varieties, respectively. The cultivation was carried out in Petri dishes each containing $25 \mathrm{~mL}$ culture medium and 30 ME were sowed per Petri dish. During the cultivation period, Petri dishes were kept at $25^{\circ} \mathrm{C} \pm 3^{\circ}$ in darkness.

The transformation was carried out with either the Agll or the LBA 4404 strains of $A$. tumefaciens, both strains carrying a binary vector which contains the gene marker gus a (gus intron) and the NPTII gene for selection, both under the control of the $35 \mathrm{~S}$ promoter.

The Agl1 strain was cultivated in medium containing $5 \mathrm{gL}^{-1}$ mannitol, $1 \mathrm{gL}^{-1}$ glutamine, $5 \mathrm{gL}^{-1}$ Triptone, $2.5 \mathrm{gL}^{-1}$ yeast extract, $0.25 \mathrm{gL}^{-1} \mathrm{KH}_{2} \mathrm{PO}_{4}, 0.1 \mathrm{gL}^{-1} \mathrm{NaCl}$ and $0.1 \mathrm{gL}^{-1}$ $\mathrm{MgSO}_{4} 7 \mathrm{H}_{2} \mathrm{O}$ at $\mathrm{pH}$ 7. One hundred $\mathrm{mgL}^{-1}$ carbenicilin and $50 \mathrm{mgL}^{-1}$ kanamicin were added as selection antibiotics for the bacterium and plasmid, respectively. The LBA 4404 strain was cultivated in minimal medium (Lichtenstein and Draper, 1986) containing $100 \mathrm{mgL}^{-1}$ rifampicin and 300 $\mathrm{mgL}^{-1}$ streptomicin as bacterial selection antibiotics and 50 $\mathrm{mgL}^{-1}$ kanamicin for plasmid selection.

For transformation, groups of approximately 30 calli were cut into small portions which were inoculated with $4 \mathrm{~mL}$ of the bacterial suspension $\left(\mathrm{OD}_{600} 0.5-0.7\right)$, allowing contact for $10 \mathrm{~min}$. Then the bacterial suspension was removed and a sterile absorbent paper was used to eliminate the bacterial suspension excess by gently blotting. The calli sections were then transferred to MSc medium. After four days of co-cultivation, the calli were transferred into the selection medium, i.e. MSc containing $10 \mathrm{mgL}^{-1}$ geneticin and 300 $\mathrm{mgL}^{-1}$ cefotaxime. The callus portions showing growth were then selected from each subculture and transferred into $\mathrm{MSr}$ (Murashige and Skoog medium to which $1 \mathrm{mgL}^{-1}$ of 6 - ( $\gamma, \gamma$-dimethylallylamino) purine, $30 \mathrm{~g} \mathrm{~L}^{-1}$ of sucrose and $8 \mathrm{~g} \mathrm{~L}^{-1}$ of agar were added, $\mathrm{pH} 5$ ) containing geneticin, but no cefotaxime. This plant material was then kept under a $16 \mathrm{hrs}$ of photoperiod $\left(48 \mu \mathrm{mol} \mathrm{s}^{-1} \mathrm{~m}^{-2}\right)$. After one month in regeneration medium, the differentiated green areas were selected and cultivated for 60 days more. Sections of calli selected before the cultivation into regeneration medium and also those organs differentiated after the regeneration stage, were also evaluated looking at the possible expression of the gus a gene by quantification of the blue stain arising from substrate transformation by the $\beta$ glucuronidase activity. 
Table 1. Callus induction, transformation, selection and plantlet regeneration from mature embryos of three onion varieties using Agl1 GI and LBA 4404 GI Agrobacterium tumefaciens strains as transfection vectors.

\begin{tabular}{|c|c|c|c|c|c|c|c|c|c|c|c|c|c|c|}
\hline \multirow{2}{*}{$\begin{array}{c}\text { Onion } \\
\text { Varieties }\end{array}$} & \multirow{2}{*}{$\begin{array}{c}\text { Cultivated } \\
\text { ME }\end{array}$} & \multirow{2}{*}{$\begin{array}{c}\text { Callus } \\
\text { induction (\%) }\end{array}$} & \multicolumn{3}{|c|}{$\begin{array}{c}\text { Transformed } \\
\text { calli }\end{array}$} & \multicolumn{3}{|c|}{$\begin{array}{l}\text { Selected callus } \\
\text { pieces }\end{array}$} & \multicolumn{3}{|c|}{$\begin{array}{l}\text { Calli with green } \\
\text { areas }\end{array}$} & \multicolumn{3}{|c|}{$\begin{array}{l}\text { Regenerated } \\
\text { plants }\end{array}$} \\
\hline & & & Agl1 & LBA & Total & Agl1 & LBA & Total & Agl1 & LBA & Total & Agl1 & LBA & Total \\
\hline Torrentina & 662 & 37.0 & 136 & 105 & 241 & 73 & 269 & 342 & 13 & 41 & 54 & 0 & 1 & 1 \\
\hline Cobriza & 178 & 88.7 & 64 & 51 & 115 & 0 & 0 & 0 & 0 & 0 & 0 & 0 & 0 & 0 \\
\hline G. de Oro & 210 & 95.2 & 85 & 91 & 176 & 0 & 0 & 0 & 0 & 0 & 0 & 0 & 0 & 0 \\
\hline Total & 1050 & 57.4 & 285 & 247 & 532 & 73 & 269 & 342 & 13 & 41 & 54 & 0 & 1 & 1 \\
\hline
\end{tabular}

About $0.5 \mathrm{~g}$ fresh leaves from putative transgenic in vitro plants was collected for PCR analysis. DNA was isolated from these plants via a miniprep protocol. PCR was performed with specific primers for uidA and for hpt. The PCR cycle was $94^{\circ} \mathrm{C}$ for $2 \mathrm{~min}(1 \mathrm{cycle}) ; 94^{\circ} \mathrm{C}$ for $1 \mathrm{~min}$, $56^{\circ} \mathrm{C}$ for $1 \mathrm{~min}, 72^{\circ} \mathrm{C}$ for $2 \min (35$ cycles $) ; 72^{\circ} \mathrm{C}$ annealing extension for $10 \mathrm{~min}$. Primers for uidA amplify a sequence of $710 \mathrm{bp}$, while $h p t$ primers amplify a sequence of $1.2 \mathrm{~kb}$.

\section{RESULTS AND DISCUSSION}

Callus induction, during three to four months, was quite variable among varieties, being particularly low $(37 \%)$ for Torrentina (Table 1). Calli were mainly of the compact type. Great variability in callus induction and plant regeneration among genotypes was reported previously (Tanikawa et al. 1998; Zheng et al. 1998; Zheng et al. 1999) and also in local varieties (Marinangeli et al. 2005).

At the end of the selection period 342 portions of calli were transferred to the regeneration medium, 73 came from the transformation with Agl1 strain and 269 from the transformation with LBA $4404 \mathrm{~A}$. tumefaciens strain, all of them belonging to the Torrentina variety (Table 1). Callus pieces from the other varieties don't shown tissue proliferation in selection medium. This fact indicates that the selection antibiotic's concentration was high for Cobriza and Grano de oro. At the end of the first subculture in MSr, 54 calli were considered potentially organogenic because of the green areas they exhibited, 13 belonged to the transformation with the Agll strain and the other 41 calli came from the LBA 4404 strain. At the end of the regeneration period only one normal plant coming from the last transformation was obtained. PCR analysis of this plant was negative, without amplification fragments for gus a nor NPTII.

The fact of being able to recover calli of only one of the three varieties demonstrates the genotypic variability that this onion varieties exhibited in the tolerance to the antibiotic geneticin and, in this way, to the transformation mediated by A. tumefaciens. Zheng et al. (2001) demonstrated that both subspecies (onion and shallot) and cultivar were important factors for a successful transformation: shallot was better than onion and even some varieties better than others.

A different quantity of selected calli was also obtained from the transformation with each one of the two A. tumefaciens strains. Probably this may not be the result of a difference in the efficiency of the transgenes transfer to the Torrentina variety, but of a higher aggressiveness of the Agl1 strain which produced death of calli in the first stages of the selection and high proportion of bacterial overgrowth (data not shown). In fact, Zheng et al. (2001) found not differences in onion transformation efficiency working whit the super-virulent EHA 105 and the ordinary LBA $4404 \mathrm{~A}$. tumefaciens strains.

Forty two per cent of selected calli evaluated through the glucuronidase expression, presented extensive blue stained areas or were completely blue. On the other hand, the tissues evaluated at the end of the regeneration period did not presented neither partial nor total blue coloration.

The production of a high proportion of calli which were unable to express or just partially express the gus gene, could be the result of a low selection pressure which could otherwise produce undesirable transgenic chimerical plants. This limitation could probably be removed by using a higher concentration of the selection agent geneticin from the beginning of selection or even in later culture transfers. Zheng et al. 2001 proved that geneticin was not successful as selective agent in ME derived calli transformation. On the other hand, he proved hygromicin as effective selective antibiotic.

\section{CONCLUDING REMARKS}

Although it was not possible to recover transgenic plants yet, this work clearly represents an advance in the endeavour of obtaining a genetic transformation from a 


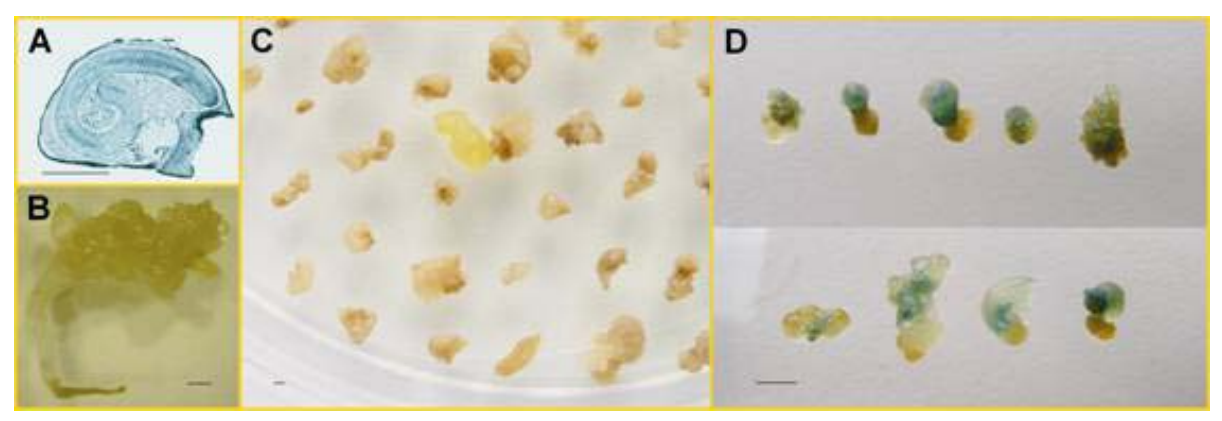

Figure 1. (a) Onion seed cutting showing mature embryos. (Modified from http://www.botany.hawaii.edu/faculty/webb/Bot201/Angiosperm/onion_embryo_developmentM.htm). (b) Callus from ME of Torrentina variety. (c) Calli after three months cultivation in selection medium. (d) Calli pieces selected after four months in selection medium showing $\beta$-glucuronidase expression. Bars represent 1 millimetre.

local variety of onion, as it was shown by recovering calli exhibiting a marked glucuronidase expression.

Differences in sensitivity to geneticin among varieties and poor in vitro plant regeneration rate shown by this species would be the main limiting steps in the whole process of obtaining transgenic plants of onion local varieties.

\section{REFERENCES}

EADY, C.C.; WELD, R.J. and LISTER, C.E. Agrobacterium tumefaciens-mediated transformation and transgenic-plant regeneration of onion (Allium cepa L.). Plant Cell Reports, 2000, vol. 19, no. 4, p. 376-381.

LICHTENSTEIN, C. and DRAPER, J. Genetic engineering of plants. In: GLOVER, D.M. ed. DNA cloning: A practical approach. IRL Press, Oxford, vol. 2, p. 67-119, 1986.

LYDIATE, D.; DALE, P.; LAGERCRANTZ, U.; PARKIN, Y. and HOWELL, P. Selecting the optimum genetic background for transgenic varieties, with examples from Brassica. Euphytica, 1995, vol. 85, no. 1-3, p. 351358.

MARINANGELI, P.; ZAPPACOSTA, D.; GALMARINI, C. and CURVETTO, N. Callus induction and plant regeneration in onion (Allium cepa L.). Acta Horticulturae, 2005, vol. 688, p. 301-308.

MURASHIGE, T. and SKOOG, F. A revised medium for rapid growth and bioassays with tobacco tissue cultures. Physiologia Plantarum, October 1962, vol. 15, p. 473-497.

TANIKAWA, T.; TAKAGI, M. and ICHII, M. Varietal differences in plant regeneration from solid and suspension cultures in onion (Allium cepa L.). Journal of the Japanese Society for Horticultural Science, 1998, vol. 67, no. 5, p. 856-861.

ZHENG, S.; KHRUSTALEVA, L.; HENKEN, B.; SOFIARI, E.; JACOBSEN, E.; KIK, C. and KRENS, F.A. Agrobacterium tumefaciens-mediated transformation of
Allium cepa L.: the production of transgenic onions and shallots. Molecular Breeding, 2001, vol. 7, no. 2, p. 101115 .

ZHENG, S.J.; HENKEN, B.; SOFIARI, E.; KEIZER, P.; JACOBSEN, E.; KIK, C. and KRENS, F.A. Effect of cytokinins and lines on plant regeneration from long-term callus and suspension cultures of Allium cepa L. Euphytica, 1999, vol. 108 , no. 2 , p. 83-90.

ZHENG, S.; HENKEN, B.; SOFIARI, E.; JACOBSEN, E.; KRENS, F.A. and KIK, C. Factors influencing induction, propagation and regeneration of mature zygotic embryoderived callus from Allium cepa. Plant Cell, Tissue and Organ Culture, 1998, vol. 53, no. 2, p. 99-105. 